\title{
Responsibly competent: Teaching, ethics and diversity
}

\author{
Julie Allan, University of Stirling
}

\section{Introduction}

The Council of Europe White paper on intercultural dialogue, Living Together as Equals in Dignity (Council of Europe, 2008a), whilst underlining the common responsibility, among us all, for fostering intercultural dialogue, identify educators at all levels as playing an 'essential role' (p. 32). The role places obligations on teachers to promote tolerance and understanding among diverse populations and to challenge negative attitudes. Yet, as the social capital theorist Robert Putnam (2007), has argued, diversity produces fear and leads people to disconnect from one another. He contends that diversity is a threat to democracy, citing evidence that in areas of high levels of ethnic diversity, people desist from associating with others and 'hunker down - that is, to pull in like a turtle' (2007, p. 149). For beginning teachers, diversity produces significant fear and they see themselves as needing to acquire highly specific and narrow skills in order to address the perceived deficits among their pupils and manage diversity in their classrooms (Allan, 2008; Gallagher, 2010; Rizvi, 2009). Many of the textbooks available to beginning teachers reinforce such expectations (Brantlinger, 2006; Sleeter, 1987): the realities presented in these texts bear little resemblance to the children whom the student teachers encounter and the certainty that they command make them irresponsible (Allan \& Slee, 2008; Brantlinger, 2006). A narrow view of teaching as involving the management of diversity is unlikely to enable teachers to foster intercultural dialogue and could lead to discrimination and exclusion (Oliver, 1996). The White Paper's authors, acknowledging the impossibility of prescribing dialogue across cultures and ethnicities in law, offer the White Paper as an 'open invitation' (p. 5). This paper reports on a project undertaken within Council of Europe, Policies and Practices for Socio-cultural Diversity that has responded to this invitation, although perhaps not as anticipated. The paper charts the progress of the project and its culmination in the development of a framework of competences for diversity that was influenced by ideas from Levinas' ethics $(1969 ; 1999)$. The paper reports on the engagement with the key stakeholders - policymakers, teachers and students throughout the project - and on how their interests were both recognised and responded to. The framework of competences for teachers that was developed, with its 
emphasis on values and teacher capacities to respond to diversity, rather than on discrete skills, is understood, in Levinisian terms, as both ethical and responsible.

\section{The Council of Europe project: Dialogue with (a) difference}

Teacher education for democratic education and human rights was established by Council of Europe as a priority following a declaration by the European Ministers of Education at its conference in 2007. The project, Policies and Practices for Socio-cultural Diversity, commenced in 2006 and was co-ordinated Council of Europe's Head of the Division of Citizenship, Human Rights and Diversity and Secretary to the Steering Committee for Education, within the Directorate of Education and Langages, Villano Qriazi, and chaired by Anne-Lise Arneson, from Norway. Researchers from Scotland (author), Austria, Bulgaria, Estonia Cyprus, Greece and France participated. The project was undertaken in three phases and began with a survey of teacher education programmes within Europe, examining how well diversity was covered. Phase 2 developed an analysis of concepts, principles and challenges for teacher education for diversity and the project concluded, in phase three, with the establishment of a framework of competences for diversity. The framework was taken on the road to a series of national Consultation Tables, held in Austria, Bulgaria, Cyprus and Estonia and involving member state officials, government officers, teacher educators, managers, researchers, principals, teachers and students. Following discussion in each of these Consultation Tables, the framework of competences was revised.

The survey, carried out in Phase 1, found that in many parts of Europe initial teacher education did not adequately prepare beginning teachers to cope with the diversity which they met in their classrooms (Council of Europe, 2008b). In analysing the concepts, principles and challenges for teacher education, the project participants identified a number of problemes which made the development of effective teacher education for diversity a complex task (Council of Europe, 2008b). One key issue is the increasing complexity and diversity of European societies and the limited, partial and outdated understandings of these societies, the needs and issues of particular groups within them, and the appropriate educational responses (OECD, 2005; Rizvi, 2009). A second issue concerns structural causes of inequalities and exclusion, including inadequate educational policies and legal frameworks. These are important in underlining responsibilities and obligations towards building diverse democratic societies but may themselves produce produce inequalities and exclusion or place 
constraints on the development of diversity within countries. If these structural barriers are not adressed by member states, too much of a burden is placed upon teacher education to support beginning teachers in responding effectively to diversity. The capacity of Teacher Education Institutions to develop teacher competences was identified as a problem: The survey of Teacher Education Institutions found that the experience and expertise of the teacher educators themselves was limited and there was a lack of relevant institutional policies.

Whilst these issues clearly made the task of improving teacher education in relation to diversity a significant challenge, the project team viewed it as one which could be taken up. There was an expectation, from within Council of Europe, that the response to the challenge would take the form of the establishment of teacher competences for diversity, which could 'serve as a common denominator' (Council of Europe, 2009, p. 12). Although the project team viewed competences, and governments' and organisations' attraction to them as part of the form part of a complex 'governance turn' (Ball 2009, p. 537; Ozga 2009), catching teachers and teacher educators web of accountability which emphasises proving rather than improving (Ball, 2000), we envisaged scope for reframing and reorienting them. This reframing and reorientation of a competence framework was undertaken in relation to ethics and is discussed below.

\section{Becoming competent, becoming ethical}

The origins of the term competence can be seen in the Greek notion of 'arête' and the Roman term 'virtus', and is generally understood as being concerned with 'what people can do rather than what they know'. It can be attributed to individuals, social groups or institutions, and the words 'competence,' 'competency' or the plural form 'competencies,' are often used interchangeably. The term has a large variety of meanings, and it can be captured by the terms 'ability', 'aptitude,' “capability,' 'effectiveness' and 'skill' (Weinert 1999). Competence can be attributed to individuals, social groups or institutions possessing or acquiring attributes that enable them to meet demands presented by the external environment (Weinert 1999). However, the notion of competence, and its plural, 'competences,' have, in recent years, been replaced by the narrower version of 'competency,' or the plural form 'competencies,' denoting discrete skills and activities which individuals can perform. The terms are often used interchangeably without an appreciation of their different meanings. 
Competence surfaced as a concept within teacher education in the early 1990s and has been firmly embedded within standards frameworks for the accreditation of teachers across Europe. However, these standards have been recognised as being problematic. Roy (2003) argues that they envelop the student teacher within rigid stratifications which deny complex thinking and firmly entrench their novice and incompetent identities. They have been viewed as invalid indicators of good teaching (Smyth and Shacklock, 1998; Mahoney and Hextall, 2000) and as part of the 'struggle over the teacher's soul' (Ball, 2003, p. 217). When the standards have been applied to diversity, the effects have been sinister, pushing the new teacher towards the management of, rather than engagement with, difference. Teachers merely have to perform the diversity related standards, without necessarily committing to the values associated with them. And since there has been little attempt to specify what effective engagement with diversity might look like, it is inevitable that scrutiny of these particular standards will be 'light touch' compared with the attention given to those associated with the more visible aspects of teaching such as classroom management. Such a framing of competences is irresponsible because it makes few demands on beginning teachers to engage with the diversity in his or her classroom other than by problematising it and seeking to limit its impact. This problematising of diversity creates, as Critchley (1999) suggests, a forgetfulness of the Other and produces inequality and injustice.

The White Paper takes up competences as a necessity for promoting intercultural dialogue but suggests that these competences 'are not automatically acquired: they need to be learned, practised and maintained throughout life' (Council of Europe, 2008a, p. 29). The Paper identifies three key competence areas: democratic citizenship, language and history. These are detailed as important areas of experience both in and out of school, but what is not made clear is the nature of teachers' competence in order to facilitate these, although the warning against using history teaching as 'an instrument of ideological manipulation, of propaganda or ... for the promotion of intolerant and ultra-nationalistic, xenophobic, racist or anti-Semitic ideas' (p. 30) gives some indication of what teachers are expected not to do.

Levinas' ethics $(1969 ; 1999)$ makes it possible to rethink the notion of teacher competence for diversity as a relationship of responsibility, directed at all students within the classroom. Such an ethics, constituting a reorientation to human subjectivity, stems from disappointment at the failure to be responsible for the Other, and at the forgetfulness of that Other, especially that Other who is different in some way, and aspires to 'be able to face and 
face down the iniquities of the present' (Critchley 2007, 88). An ethics has as its core an absolute responsibility to the Other and the relationship is experienced, because of an inadequacy in the face of the Other, as asymmetrical (rather than as one of equals which the White Paper advocates) and as not benign, but as a responsibility that 'persecutes me with its sheer weight' (Critchley 2007, 59). This produces an absolute imperative towards the Other which is a 'gratuitous and non-transferable responsibility, as if they were chosen and unique and in which the other were absolutely other, i.e ... still incomparable and thus unique' (Levinas 1999, 170). The responsibility, according to Levinas, is inescapable:

to be a "self" is to be responsible before having done anything ... I am not merely the origin of myself, but I am disturbed by the Other. Not judged by the Other, but condemmed without being able to speak, persecuted' (Levinas, 1996, p. 94).

The responsibility to the Other is both 'indeclinable' (Levinas, 1998 p. 134), so we cannot say 'no' to it, and inifinite:

The idea of the infinite consists precisely and paradoxically in thinking more than what is thought while nevertheless conserving it in its excessive relation to thought. The idea of the infinite consists in grasping the ungraspable while nevertheless guaranteeing its status as ungraspable (Levinas, 1969, 19).

The responsibility that one has to the Other operates at three levels: responding to the Other; responding for oneself to the Other and responding for the other, by substituting oneself for the other person in its responsibilities (Hutchens, 2004). And whilst these are heavy responsibilities, as Butler (2003) reminds us, being disturbed by the obligation of the Other is a vital part of what it is to be human: 'Let's face it. We're undone by each other. And if not, we're missing something' (p. 43). Biesta's (2008) notion of 'pedagogy with empty hands' (p. 198 ) is an extremely useful way of thinking about education from an ethical point of view. It requires teachers to approach students within their classroom - without ready solutions or 'tricks of the trade' (p. 208), derived from textbooks, research or elsewhere, and to ask 'what 
do you think of it?' (p. 208). This notion of constant readiness is something of a departure from the idea of a teacher whose lessons, activities and outcomes are planned ahead and whose actions in class can be predicted. It does, however, appear more likely to enable teachers to be able to respond to diversity in whatever shape or form it surfaces.

In considering the competences required by teachers for diverse democratic societies within the project, we posed the question, from an ethical standpoint, what do we want our teachers: to understand?; to be? to do? We suggested that teacher competence for diverse democratic societies could not reasonably be viewed as consisting of fixed amounts of knowledge, skills or behaviours to be acquired by teachers, but that it must be responsive to the changing nature of the society in which the teacher works and subject to the teacher's continuous reflection and adaptation. This representation of the competent teacher in relation to diversity met with a positive response from the participants in the Consultation tables, especially the teachers, teacher educators and students, and indeed one teacher from Estonia offered an image of the teacher as gardener. This kind of teacher, she explained, had to be always ready and adaptive to the different demands of the various species in her classroom. She had to be prepared to provide different amounts of water, nourishment and protection to each indiviudal and to recognise that they would flourish in different ways. Above all, this teacher, contended, the teacher had to love each one of her charges. The image of the teacher as gardener resonated well with the development of competences which were ethical and which principally concerned the relationship between the teacher and his or her learners.

The framework, in its final form, contains three clusters of competences. In the centre, and central, is Communication and Relationships. The competences within the clusters of competences which flanked Communication and Relationships, Knowledge and Understanding and Management and teaching, would, we argued, be of a second order to, and developed from the acquisition of competences in, Communication and Relationships. Fundamentally, we argued, these competences were, not finite skills that could be demonstrated, but requiring continuous development and review.

Table about here: 
The framework was published within the third of the Project's reports (Council of Europe, 2010a) and is now in the public domain. The essence of the ethical approach informed some of the advice in support of the 23rd Council of Europe Ministerial Conference, Teacher Education for a Sustainable Democratic Society, which took place in June, 2010 in Ljubljana, Slovenia. Ministers were invited to consider teacher competences, alongside the status and conditions of teachers and partnership working. Acting in the role of Expert Adviser to the Council of Europe and taking responsibility for teacher competences, I conveyed the ethical approach to competences to the Ministers, but did not name it as such. Ministers were advised that although the challenge of developing competences for diverse democratic societies was both enormous and complex, there was clearly much that member states could do which was not dependent on vast amounts of resources, specialised technical knowledge or personnel, but which involved finding ways of simultaneously creating opportunities and removing barriers to dialogue and participation. Their response was one of recognition and desire and although such formal events can be more memorable for their Ministerial platitudes than for their evidence of transformatory thought, the subsequent declaration which the Ministers' signed up to expressed a significant commitment to and responsibility for the Other and an intent to remove barriers to intercultural dialogue (Council of Europe, 2010b):

RECOGNISING that, in times of global economic crisis, European societies are facing many challenges such as increasing inequality and social exclusion, which threaten the fundamental principles of socially sustainable societies including equal opportunities and social justice ... CONSIDERING that all teachers and other education professionals are one of the essential pillars of the process of building sustainable democratic societies and need to develop the necessary transversal competences; these are interrelated knowledge, skills and attitudes enabling teachers to model democratic and participatory processes based on respect for human rights, diversity and human dignity (pp. 2-3).

Beyond the formal language of the Declaration, the Ministers can be seen highlighting the centrality of teachers as agents of intercultural dialogue and signalling the importance of teacher education in equipping teachers effectively and appropriately - enabling them to be democratic citizens in order to cultivate these values and attributes among their students. 
Ethics, even if they were just implied, had been invited along to the Ministerial dialogue and appeared to have been a welcome guest.

\section{Conclusion: Infinitely competent?}

[Ethics] being utopian does not prevent it from investing our everyday actions of generosity or goodwil towards the other: even the smallest and most commonplace gestures, such as saying 'after you' as we sit at the dinner table or walk through a door, bear witness to the ethical (Levinas, 1986, p. 32).

The Council of Europe issues a challenge to address the inequalities produced by an education system that insists that 'everyone do better than everyone else' (McDermott, 1993, p. 274). The pathologising and naming of individual deficits within that system represents what Thomas (2007) calls a 'closure on learning (p. 7) which produces and reinforces disabled, ethnic, class and gendered identities as failures and as Gillborn and Youdell (2000) have documented, there is a channeling (and rationing) of educational support away from these individuals and towards those most likely to benefit. Teachers, through no fault of their own, lose sight of the Other or, worse still, become afraid of the diversity that the Other brings and beginning teachers are encouraged to think of diversity as a problem to be managed within the classroom.

Levinas's ethics offers the possibility of rethinking the relationship between teachers and students as a dialogue. Diversity, within such a dialogue, becomes a central and inevitable element and something which the teacher must be ready - and eager - to respond to. Teacher education, in preparing the beginning teacher's readiness must also take the form of a dialogue within which they can articulate anxieties and questions, rather than rehearse the dogma of tolerance. It was possible to introduce a Levinasian ethics into the process of establishing a framework of competences through a series of contingent elements. First, there was the Council of Europe and its commitment to dialogue beyond a rhetorical level. The Council of Europe's relative lack of power compared with the European Union is its strength, as it leaves it free to guide in a more ethical and responsible way. Villano Qriazi successfully managed the project as an intercultural dialogue, enabling it to develop along these ethical lines, whilst also having regard for the expectations of the Council of Europe and a detailed knowledge of how best to communicate complex ideas to policymakers and politicians. The 
researchers who participated in the project, whilst not all familiar with Levinas' ethics, brought a commitment to helping teachers towards greater recognition of, and confidence with, diversity. Thus, an ethical approach was possible, within the structure and ethos of the Council of Europe and through a dialogue that was itself intercultural and, above all, responsible.

The ethical framework of competences were presented as far from being a solution to the 'problem' of diversity; rather, diversity itself, and teachers relationship with it and with the Other, was its own solution. Re-presenting competences as ethical, using the recognisable language and structures of the comptences themselves, appears to have engaged, then redirected that engagement, in more responsible ways. It remains to be seen whether this particular competence framework will be used in the way we have intended, and as Levinas has suggested, to develop a teaching relationship in which the teacher, as well as the student, is taught. One might hope that it can at least provoke, among teachers and teacher educators, a dialogue that has at its heart responsibility. After you?

\section{References}

Allan, J. (2008) Rethinking inclusive education: The philosophers of difference in practice. Dordrecht: Kluwer.

Allan, J. \& Slee, R. (2008). Doing inclusive education research. Rotterdam: Sense.

Ball, S. (2000) Performativities and fabrication in the education economy: Towards the performative society? Australian Educational Researcher, 27(2), 1-23.

Ball, S. (2003) The teacher's soul and the terror of performativity. Journal of Education Policy, 18(2), 215-228.

Ball, S. (2009) The governance turn! Editorial. Journal of Education Policy 24, no. 5, 537538.

Biesta, G. (2008) Pedagogy with empty hands: Levinas, education and the question of being human. In D. Egéa-Kuehne (Ed) Levinas and education: At the intersection of faith and reason. London/New York: Routledge. 
Brantlinger, E. (2006) The big glossies: How textbooks structure (special) education. In E. Brantlinger (Ed) Who benefits from special education? Remediating (fixing) other people's children. Mahwah, New Jersey/London: Lawrence Erlbaum Associates.

Butler, J. (2004) Precarious lives. London: Verso.

Council of Europe (2008a) Living together as equals in dignity. White Paper. Strasbourg: Council of Europe.

Council of Europe (2008b) Policies and practices for teaching sociocultural diversity: A Survey Report. Strasbourg: Council of Europe.

Council of Europe (2009) Policies and practices for teaching sociocultural diversity: Concepts, principles and challenges in teacher education. Strasbourg: Council of Europe.

Council of Europe (2010a) Policies and practices for teaching sociocultural diversity: Concepts, principles and challenges in teacher education: Strasbourg: Council of Europe.

Council of Europe (2010b) Standing Conference of Ministers of Education. Teacher education for a sustainable democratic society. 23rd Session, 4-5 June. Declaration on the conference theme. http://www.coe.int/t/dg4/education/standingconf/MED-23$14 \% 20 \mathrm{E} \% 20$ Declaration.pdf

Critchley, J (1999) The ethics of deconstruction. Edinburgh: Edinburgh University Press.

Critchley, J. (2007) Infinitely demanding: Ethics of commitment, politics of resistance. London/New York: Verso.

Gallagher, D. (2010) Hiding in plain sight: The nature and role of theory in learning disability labelling. Disability Studies Quarterly, 30. http://www.dsqsds.org/article/view/1231/1278

Gillbourn, D and Youdell, D (2000) Rationing education: Policy, practice, reform and equity. Buckingham: Open University Press.

Hutchens, B. (2004) Levinas: A guide for the perplexed. London: Continuum.

Levinas, E. (1969) Totality and infinity. Pittsburgh: Duquesne University Press. 
Levinas, E. (1986) Dialogue with Emmanuel Levinas. Interview by Richard Kearney. In R. A. Cohen (Ed) Face to face with Levinas. Albany: State University of New York Press.

Levinas, E. (1999) Alterity and transcendence. Columbia University Press: New York.

Levinas, E. (1998) Collected philsophical papers. Trans. A. Lingis. Pittsburgh, PA: Duquesne University Press.

McDermott, R. P. (1993) The acquisition of a child by a learning disability. In C. Chaiklin \& J. Lave (Eds) Understanding practice: Perspectives on activity and context. New York: Cambridge University Press.

Mahony, P. \& Hextall, I. (2000) Reconstructing teaching: standards, performance and accountability. London: Routledge Falmer.

Oliver, M. (1996) Understanding disability: From theory to practice. Basingstoke: Macmillan.

OECD (2005) The definition and selection of key competencies. www.oecd.org/dataoecd/47/61/35070367.pdf

Ozga, J. (2009) Governing education through data in England: from regulation to selfevaluation. Journal of Education Policy, 24(2), 149-162.

Putnam, R. (2007) E pluribus unum: Diversity and community in the twenty-first century. The 2006 Johan Skytte Prize lecture. Nordic Political Science Association, 30, 137-174.

Rizvi, F. (2009) Working with diversity in transnational contexts. Keynote address. Diversity and inclusion: challenges for teacher education. Final conference of the Council of Europe Project 'Policies and Practices for Socio-cultural diversity. Oslo, 26-28 October.

Roy, K. (2003) Teachers in nomadic spaces: Deleuze and curriculum. New York: Peter Lang.

Sleeter, C. (1987) Why is there learning disabilities? A critical analysis of the birth of the field in its social context. In T. Popkewitz (Ed), The formation of school subjects: The struggle for creating an American institution. London: Falmer Press.

Smyth, J. \& Shacklock, G. (1998) Remaking teaching: ideology, policy and practice. London: Routledge. 
Thomas, G. (2007) Theory and the construction of pathology. Paper presented at the American Educational Research Association, New York, 24-28 March.

Weinert, F. E. (2001) Concept of Competence: A Conceptual Clarification. In D. S. Rychen \& L. H. Salganik (Eds.) Defining and Selecting Key Competencies. Seattle: Hogrefe \& Huber. 
Table: Teacher competences for diversity

\begin{tabular}{|c|c|c|}
\hline $\begin{array}{l}\text { Knowledge and } \\
\text { understanding }\end{array}$ & $\begin{array}{l}\text { Communication and } \\
\text { relationships }\end{array}$ & Management and teaching \\
\hline Competence 1 & Competence 7 & Competence 13 \\
\hline \begin{tabular}{|} 
Knowledge and \\
understanding of the \\
political, legal and structural \\
context of socio-cultural \\
diversity
\end{tabular} & $\begin{array}{l}\text { Initiating and sustaining positive } \\
\text { communication with pupils, } \\
\text { parents and colleagues from } \\
\text { different socio-cultural } \\
\text { backgrounds }\end{array}$ & $\begin{array}{l}\text { Addressing socio-cultural } \\
\text { diversity in curriculum and } \\
\text { institutional development }\end{array}$ \\
\hline Competence 2 & Competence 8 & Competence 14 \\
\hline $\begin{array}{l}\text { Knowledge about } \\
\text { international frameworks and } \\
\text { understanding of the key } \\
\text { principles that relate to socio- } \\
\text { cultural diversity education }\end{array}$ & $\begin{array}{l}\text { Recognising and responding to } \\
\text { the communicative and cultural } \\
\text { aspects of language(s) used in } \\
\text { school }\end{array}$ & $\begin{array}{l}\text { Establishing a participatory, } \\
\text { inclusive and safe learning } \\
\text { environment }\end{array}$ \\
\hline Competence 3 & Competence 9 & Competence 15 \\
\hline $\begin{array}{l}\text { Knowledge about different } \\
\text { dimensions of diversity, eg } \\
\text { ethnicity, gender, special } \\
\text { needs and understanding } \\
\text { their implications in school } \\
\text { settings }\end{array}$ & $\begin{array}{l}\text { Creating open-mindedness and } \\
\text { respect in the school community }\end{array}$ & $\begin{array}{l}\text { Selecting and modifying } \\
\text { teaching methods for the } \\
\text { learning needs of pupils }\end{array}$ \\
\hline Competence 4 & Competence 10 & Competence 16 \\
\hline $\begin{array}{l}\text { Knowledge of the range of } \\
\text { teaching approaches, } \\
\text { methods and materials for } \\
\text { responding to diversity }\end{array}$ & $\begin{array}{l}\text { Motivating and stimulating all } \\
\text { pupils to engage in learning } \\
\text { individually and in co-operation } \\
\text { with others }\end{array}$ & $\begin{array}{l}\text { Critically evaluating diversity } \\
\text { within teaching materials, eg } \\
\text { textbooks, videos, media }\end{array}$ \\
\hline Competence 5 & Competence 11 & Competence 17 \\
\hline $\begin{array}{l}\text { Skills of inquiry into } \\
\text { different socio-cultural issues }\end{array}$ & $\begin{array}{l}\text { Involving all parents in school } \\
\text { activities and collective decision- } \\
\text { making }\end{array}$ & $\begin{array}{l}\text { Using of a variety of } \\
\text { approaches to culturally } \\
\text { sensitive teaching and } \\
\text { assessment }\end{array}$ \\
\hline Competence 6 & Competence 12 & Competence 18 \\
\hline $\begin{array}{l}\text { Reflection on one's own } \\
\text { identity and engagement with } \\
\text { diversity }\end{array}$ & $\begin{array}{l}\text { Dealing with conflicts and } \\
\text { violence to prevent } \\
\text { marginalization and school } \\
\text { failure }\end{array}$ & $\begin{array}{l}\text { Systematic reflection on and } \\
\text { evaluation of own practice } \\
\text { and its impact on students }\end{array}$ \\
\hline
\end{tabular}

